\title{
SUNFLOWER BREEDING AT THE AGRICULTURAL
} INSTITUTE OSIJEK

Krizmanić, M. , Mijić, A., Liović, I., Bilandžić, M. and Duvnjak, T.

The Agricultural Institute Osijek, Južno predgrađe 17, HR-31000 Osijek, Croatia

Received: September 10, 2005

Accepted: March 25, 2006

SUMMARY

Sunflower breeding programs in the Republic of Croatia have over 30year tradition and they have been realized only at the Agricultural Institute Osijek. At present, the program is realized within the framework of the scientificresearch project "Breeding of hybrid sunflower for high grain yield and quality", that is partially sponsored by Ministry of Science, Education and Sport of the Republic of Croatia. Main goal is creation of superior hybrids with high grain yield (above $5 \mathrm{t} / \mathrm{ha}$ ), oil content (above $50 \%$ ) and high and stable oil yield. Special attention is given to creation of lines with emphasized tolerance to dominant pathogens and creation of hybrids with short vegetation (110 to 120 days). Until now, results of work are 12 approved hybrids (Osječanin, Fakir, Olio, Orion, Podravac, Slavonac, Sunce, Gordan, Miro, Šokac, Favorit and Apolon), which have considerably contributed to sunflower production increase in Croatia. Also, two sunflower hybrids of the Agricultural Institute Osijek (Fakir and Olio) have been approved in the Republic of Slovakia. Future work in breeding is directed to intensifying phytopathological investigation in laboratory and the use of a biotechnological method, which will contribute to higher efficiency of the breeding program.

Key words: sunflower, breeding, hybrids

\section{INTRODUCTION}

Sunflower (Helianthus annuus L.) is grown at around 20 million hectares in the world and it presents one of the most important crops for oil production. Average grain yield in the world is around 1.1 t/ha, varying from 0.5 to $3.6 \mathrm{t} / \mathrm{ha}$. In the Republic of Croatia, sunflower is the most important oil crop and it is grown mostly in its eastern part, where suitable conditions exist for sunflower growth and development. The average area is around 25,000 ha, with the average grain yield of $2.4 \mathrm{t} /$ ha. The production volume satisfies only a half of sunflower needs, so there is space for improving and developing the production for the needs of the domestic market.

\footnotetext{
* Corresponding author, e-mail: miroslav.krizmanic@poljinos.hr
} 
Sunflower breeding programs in the Republic of Croatia have over 30-year tradition and they have been realized only at the Agricultural Institute Osijek. The present breeding program is realized within the framework of the scientificresearch project "Breeding of sunflower hybrids for high grain yield and quality", which is partially sponsored by Ministry of Science, Education and Sport of the Republic of Croatia.

The experimental breeding material involves a few hundred inbred lines (CMS and restorer lines). Each year, a few hundred new hybrid combinations are created which are subsequently tested, through a network of micro- and macro trials, for stability of grain and oil yields and other important traits in breeding.

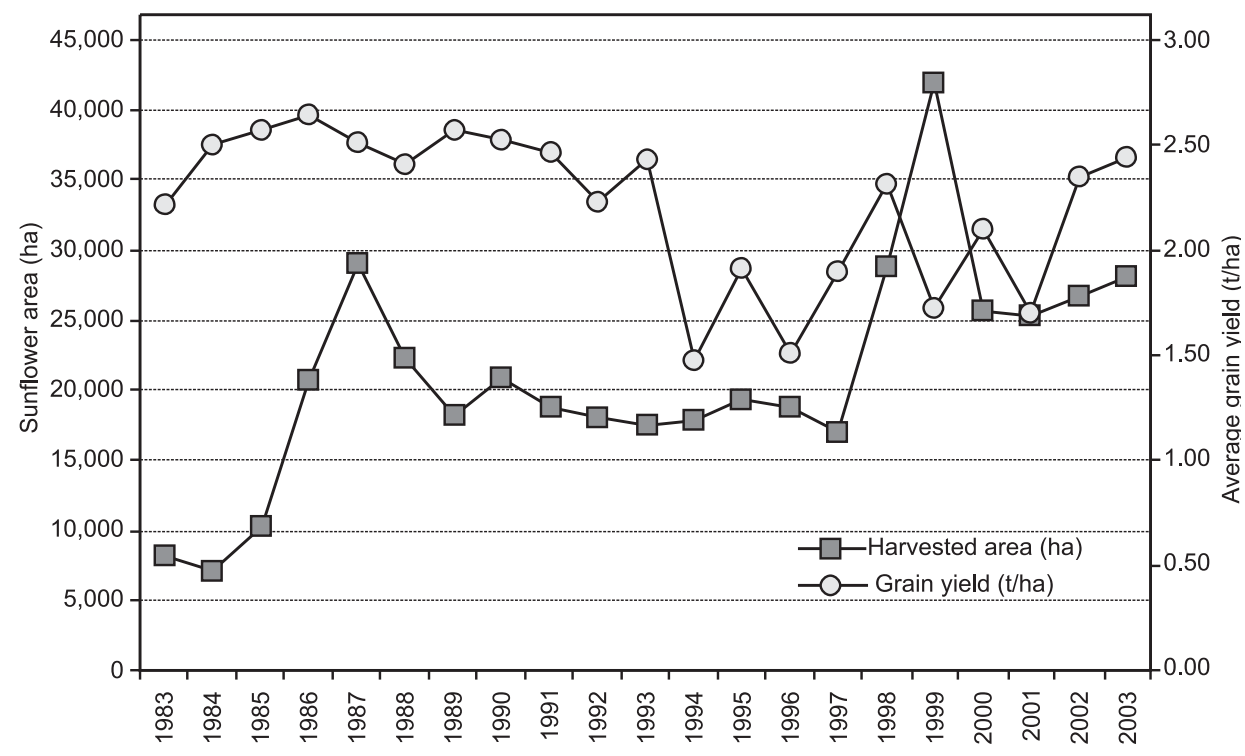

Figure 1: Sunflower area (ha) and average grain yield ( $t / h a)$ in the Republic of Croatia, 1983-2003 (FAOSTAT Database 2004)

\section{Aims of breeding}

The main objective of sunflower breeders at the Agricultural Institute Osijek is to create high-yielding hybrids, with high grain and oil yield potentials, which will keep these traits in different agroecological conditions.

We also work on other traits, those which directly or indirectly affect the yield (hectoliter mass, 1000-grain weight, husk content, drought tolerance, plant height, resistance to lodging and harvest index). A part of the program is aimed on creation of high oleic and protein sunflower.

Special attention is given to creation of lines with emphasized tolerance to dominant pathogens: Plasmopara halstedii, Alternaria helianthi, Macrophomina phaseolina, Phoma macdonaldii, Sclerotinia sclerotiorum and Phomopsis sp. 
Beside that, it is necessary to create hybrids with short vegetation (110 to 120 days), high leaf area index (LAI) and high leaf area duration (LAD).

\section{Breeding methods}

Breeding methods conventional for cross-pollinated species are used in the breeding program, while taking in consideration the specific sunflower biology. The most frequently used methods are mass selection, pedigree method and different method of divergent and convergent breeding.

Beside that, different biotechnological methods are used or will be used in near future, in order to improve analysis of genetic divergence, resistance to disease and stress conditions (tissue culture, molecular markers).

\section{RESULTS}

Until now, results of work at the Agricultural Institute Osijek are 12 approved hybrids (Osječanin, Fakir, Olio, Orion, Podravac, Slavonac, Sunce, Gordan, Miro, Šokac, Favorit and Apolon). These hybrids have considerably contributed to the development, improvement and stabilization of sunflower production in Croatia.

Also, two sunflower hybrids of the Agricultural Institute Osijek (Fakir and Olio) have been approved in the Republic of Slovakia. Our hybrids can be found in trials in Serbia and Montenegro, Turkey, Russia, Bosnia and Herzegovina, Romania, Hungary, etc.

Table 1 shows that in two climatically different years our hybrids showed high grain yield potential, oil content and oil yield as well as high drought tolerance.

Future work in breeding is directed to intensifying phytopathological investigation in laboratory and the use of a biotechnological method, which will contribute to higher efficiency of the breeding program.

Table 1: Average grain yield, oil content and oil yield in micro trials (Osijek, 2000 and 2002)

\begin{tabular}{lccc}
\hline \multirow{2}{*}{ Hybrid } & Grain yield & Oil content in DM & \multicolumn{2}{c}{ Oil yield in DM } \\
\cline { 2 - 4 } & $(\mathrm{kg} / \mathrm{ha})$ & $(\%)$ & $(\mathrm{kg} / \mathrm{ha})$ \\
\hline Orion & 4879 & 48.72 & 2163 \\
Favorit & 5765 & 50.37 & 2638 \\
Apolon & 4818 & 54.79 & 2403 \\
Fakir & 4745 & 46.19 & 2001 \\
Olio & 4165 & 50.84 & 1932 \\
Šokac & 4139 & 49.13 & 1875 \\
Exp. OS-H-8 & 4090 & 54.85 & 1981 \\
Exp. OS-H-9 & 4218 & 52.72 & 2021 \\
Exp. OS-H-18 & 4650 & 53.33 & 2151 \\
\hline Average & 4608 & 51.22 & 2129 \\
\hline
\end{tabular}




\section{CONCLUSIONS}

Our sunflower breeding program fosters a model of sunflower hybrid, which implies a successful realization of all traits, which directly and indirectly influence the grain and oil yields, under different agroecological conditions.

Creation of hybrids with good stability and wide adaptability is a high priority task in sunflower breeding at the Agricultural Institute Osijek.

\section{REFERENCES}

FAOSTAT Database 2004

Fick, G.N. and J.F. Miller, 1997. Sunflower breeding. In: Sunflower Tehnology and Production. Edited by A.A. Schneiter, ASA, CSSA, SSSA, Madison, Wisconsin, USA. pp. 395-440.

Krizmanić, M., V. Jukić, M. Vratarić and M. Bilandžić, 1989. Osnovni pravci u oplemenjivanju suncokreta u Poljoprivrednom institutu Osijek s osvrtom na karakteristike novih OShibrida suncokreta. Znan. Prak. Poljopr. Tehnol. 19(3-4): 154-171.

Krizmanić, M. and J. Martinčić, 1996. Suncokret (Helianthus annuus L.). In: Oplemenjivanje bilja. Urednici: Kozumplik, V. i J. Martinčić. Agronomski fakultet Zagreb i Poljoprivredni fakultet Osijek. pp. 309-334.

Marinković, R., B. Dozet and D. Vasić, 2003. Oplemenjivanje suncokreta. Monografija. Školska knjiga. Novi Sad.

Maširević, S., G. Forgić and N. Kurjak, 1997. Bolesti suncokreta glavni limitirajući faktor uspešnosti proizvodnje u 1997. godini. Zbornik radova. Sveska 30. Novi Sad. pp. 103114.

Škorić, D., S. Jocić, D. Jovanović and N. Hladni, 2004. Global sunflower breeding achievements. XXXIXth Croatian simposium on agriculture with international participation. pp. $172-174$.

Vratarić, M. and A. Sudarić, 2004. Oplemenjivanje i genetika suncokreta. In: Suncokret (Helianthus annuus L.). Urednik: Marija Vratarić. Poljoprivredni institut Osijek. pp. 69162.

\section{SELECCIÓN DE GIRASOL EN EL INSTITUTO AGRÍCOLA DE OSIJEK}

\section{RESUMEN}

Los programas de selección de girasol tienen una tradición de 30 años en la República de Croacia, y se llevan a cabo exclusivamente en el Instituto Agrícola de Osijek. Actualmente, el programa se está realizando dentro del proyecto científico-investigador "Selección del Girasol Híbrido en Alto Rendimiento de Grano y de Calidad", financiado parcialmente por parte del Ministerio de Ciencia, Educación y Deporte de la República de Croacia. El objetivo principal es la formación de los híbridos superiores, con alto rendimiento de granos (por encima de $5 \mathrm{t} / \mathrm{ha}$ ), contenido de aceite (por encima de 50\%) y alto y estable rendimiento de aceite. Una atención especial se está prestando en la formación de líneas con una marcada resistencia hacia los patógenos dominantes y la formación de híbridos de corta vegetación (110 a 120 días). Los resultados logrados hasta el momento son 12 híbridos registrados (Osjeèanin, Fakir, Olio, Orion, Podravac, Slavonac, Sunce, Gordan, Miro, Favorit y Apolon), que han contribuido significativamente al incremento de producción de girasol en Croacia. Además, dos híbridos de girasol del Instituto Agrícola de Osijek (Fakir y Olio) han sido registrados en la República de Eslovaquia. El futuro trabajo en la selección está orientado hacia la intensifi- 
cación de las investigaciones fitopatológicas en el laboratorio y utilización del método biotecnológico, lo que va a contribuir al incremento de eficiencia del programa de selección.

\section{CULTURE DU TOURNESOL À L'INSTITUT D'AGRICULTURE D'OSIJEK}

\section{RÉSUMÉ}

Les programmes de culture du tournesol en République de Croatie ont une tradition de plus de 30 ans et ils se font exclusivement à l'institut d'agriculture d'Osijek. Le programme se réalise présentement dans le cadre du projet de recherche scientifique "Culture du tournesol hybride pour un rendement élevé en grains et une qualité supérieure » qui est partiellement commandité par le Ministère des Sciences, de l'Éducation et des Sports de la République de Croatie. Son but principal est la création d'hybrides supérieurs ayant un grand rendement en grains (plus de $5 \mathrm{t} / \mathrm{ha}$ ), en contenu d'huile (plus de $50 \%$ ) et un rendement d'huile élevé et stable. Une attention particulière est donnée à la création de lignées ayant une tolérance accrue aux pathogènes dominants et à celle d'hybrides ayant une période de végétation brève (de 110 à 120 jours). Jusqu'à maintenant, ce travail a donné 12 hybrides homologués (Osječanin, Fakir, Olio, Orion, Podravac, Slavonac, Sunce, Gordan, Miro, Šokac, Favorit et Apolon) qui ont grandement contribué à l'augmentation de la production de tournesol en Croatie. De plus, deux hybrides de tournesol de l'Institut d'agriculture d'Osijek (Fakir et Olio) ont été homologués en République de Slovaquie. Le travail à venir dans la sélection est orienté vers l'intensification des recherches phytopathologiques en laboratoire et l'utilisation d'une méthode biotechnologique, ce qui contribuera à une plus grande efficacité du programme de sélection. 
